\title{
Short communication: Comparison of a palmitic acid-enriched triglyceride supplement and calcium salts of palm fatty acids supplement on production responses of dairy cows
}

\author{
J. de Souza and A. L. Lock ${ }^{1}$ \\ Department of Animal Science, Michigan State University, East Lansing 48824
}

\begin{abstract}
The objective of our study was to evaluate the effects of feeding a palmitic acid-enriched triglyceride supplement or a calcium salts of palm fatty acid (FA) supplement on nutrient digestibility and production responses of mid-lactation dairy cows. Fifteen Holstein cows (139 $\pm 39 \mathrm{~d}$ in milk) were randomly assigned to treatment sequence in a $3 \times 3$ Latin square design. Treatments were a control diet (CON; no fat supplement) and $1.5 \%$ of FA added either as a palmitic acid-enriched triglyceride supplement (PA-TG) or as calcium salts of palm FA supplement (Ca-FA). Fat-supplemented treatments did not affect dry matter intake (DMI) compared with CON, but Ca-FA reduced DMI compared with PA-TG. Compared with CON, fat-supplemented treatments increased 18-carbon FA digestibility by 2.0 percentage units but did not affect digestibility of total FA or 16-carbon FA. Compared with Ca-FA, PA-TG reduced total FA digestibility by 8.7 percentage units due to a decrease in 16-carbon FA digestibility (21.7 percentage units). Both fat supplements increased neutral detergent fiber (NDF) digestibility compared with $\mathrm{CON}$ (3.90 percentage units), and PA-TG tended to increase NDF digestibility by 1.60 percentage units compared with Ca-FA. Compared with CON, fat-supplemented treatments increased milk yield $(1.05 \mathrm{~kg} / \mathrm{d}), 3.5 \%$ fatcorrected milk yield $(2.20 \mathrm{~kg} / \mathrm{d})$, and energy-corrected milk yield $(1.80 \mathrm{~kg} / \mathrm{d})$. Also, PA-TG increased milk fat yield $(50 \mathrm{~g} / \mathrm{d})$ and milk energy output $(1.0 \mathrm{Mcal} / \mathrm{d})$ and tended to increase milk fat content ( 0.07 percentage units) and energy-corrected milk yield $(1.0 \mathrm{~kg} / \mathrm{d})$ compared with Ca-FA. Fat-supplemented treatments reduced the yield of de novo milk FA $(23 \mathrm{~g} / \mathrm{d})$ and increased the yields of mixed $(43 \mathrm{~g} / \mathrm{d})$ and preformed $(52$ $\mathrm{g} / \mathrm{d})$ milk FA compared with CON. The PA-TG treatment increased the yield of 16-carbon $(66 \mathrm{~g} / \mathrm{d})$ milk FA compared with Ca-FA, whereas Ca-FA increased the
\end{abstract}

Received July 24, 2017.

Accepted December 4, 2017.

${ }^{1}$ Corresponding author: allock@msu.edu yield of preformed $(60 \mathrm{~g} / \mathrm{d})$ milk FA. Fat-supplemented treatments increased intake of net energy for lactation by $1.80 \mathrm{Mcal} / \mathrm{d}$, milk energy output by $1.30 \mathrm{Mcal} / \mathrm{d}$, and energy in body reserves by $0.30 \mathrm{Mcal} / \mathrm{d}$ compared with CON. The Ca-FA treatment increased energy allocated to body reserves $(0.60 \mathrm{Mcal} / \mathrm{d})$, energy partitioning toward body reserves (1.20 percentage units), and body condition score change (0.06 units), and tended to increase body weight change $(0.16 \mathrm{~kg} / \mathrm{d})$ and body condition score (0.08 units) compared with PA-TG. In conclusion, feeding a palmitic acid-enriched triglyceride supplement increased milk energy output due to increased yields of milk and milk fat, whereas feeding a calcium salts of palm FA supplement increased FA digestibility and energy partitioned to body reserves.

Key words: palmitic acid, triglyceride, fatty acid, production, calcium salts of palm fatty acid

\section{Short Communication}

Fat supplements are commonly added to dairy cow diets to increase dietary energy density, feed efficiency, and yields of milk and milk fat, and to improve energy balance (Palmquist, 1994; Rabiee et al., 2012). One of the most common sources of rumen-protected fat is calcium salts, conceived over $30 \mathrm{yr}$ ago to minimize the negative effects of UFA on ruminal populations, especially on cellulolytic bacteria (Palmquist, 1991). Individual fatty acids (FA) can have different effects and considerable recent research has focused on palmitic acid (C16:0) supplementation. Palmitic acid has been reported to increase milk fat concentration and yield and the efficiency of milk production compared with non-fat-supplemented diets (Lock et al., 2013; de Souza et al., 2017) and with other fat supplements (Rico et al., 2014a,b). However, with the exception of Weiss et al. (2011), published studies in lactating dairy cows have evaluated the effect of palmitic acid-enriched free FA supplements rather than triglyceride (TG) supplements.

Changes in intake and nutrient digestibility due to supplemental fat may affect, positively or negatively, 
digestible energy available for milk production, body reserves, or both (Boerman et al., 2015a). Weiss et al. (2011) observed lower total FA digestibility for a palmitic acid-enriched TG supplement compared with a nonfat control diet when fed at $3 \%$ of diet DM. However, the decrease in FA digestibility was smaller than that previously reported in other studies that fed saturated TG supplements, in which total FA digestibility ranged from 33 to $62 \%$ (e.g., Pantoja et al., 1995; Elliott et al., 1999; Weiss and Wyatt, 2004). Although these results suggest that a TG supplement with a low proportion of C18:0 (and high proportions of C16:0 and C18:1) has moderate digestibility (Weiss et al., 2011), comparative data for feeding palmitic acid-enriched TG supplements to lactating dairy cows are not available. Importantly, considering that most dairy farms that use supplemental fat would include it in diets within a range of 0.5 to $2.0 \%$ of ration $\mathrm{DM}$, determining the effects of a palmitic acid-enriched TG supplement within this range has important applications. Therefore, characterizing the effects of feeding a palmitic acid-enriched TG supplement under typical feeding conditions is of particular importance.

The objective of the current experiment was to characterize the effects of feeding a palmitic acid-enriched TG supplement on nutrient digestibility and production responses of mid-lactation dairy cows compared with a nonfat control and the well-investigated supplement, calcium salts of palm FA. We hypothesized that the calcium salts of palm FA supplement would have higher digestibility than the TG supplement but that the differences would be smaller than previously reported in the literature due to differences in the FA profile of the TG supplement. Additionally, we postulated that the TG supplement would increase milk FA yield to a greater extent than the calcium salts of palm FA supplement due to differences in the FA profile of the supplemental fats.

Experimental procedures were approved by the Institutional Animal Care and Use Committee at Michigan State University (East Lansing). Fifteen mid-lactation Holstein cows at the Michigan State University Dairy Field Laboratory were randomly assigned to treatment sequence in replicated $3 \times 3$ Latin squares with 21 -d periods. All animals received a common diet with no supplemental fat during a 14-d preliminary period to obtain baseline values. At the beginning of the trial, mean $( \pm \mathrm{SD})$ DIM, BW, and milk yield were $139 \pm 39$ $\mathrm{d}, 690 \pm 44 \mathrm{~kg}$, and $51.4 \pm 4.5 \mathrm{~kg} / \mathrm{d}$, respectively.

Treatments were a control diet $(\mathbf{C O N}$; no supplemental fat) and $1.5 \%$ of FA added either as a palmitic acid-enriched TG supplement (PA-TG) or as calcium salts of palm FA supplement (Ca-FA). The fat supplements replaced soyhulls in the diets (Table 1 ). Both fat- supplemented diets were balanced for glycerol concentration; glycerol was not added to the CON treatment. Although it is important to consider possible different metabolic fates for the glycerol fed in the diet and that released from TG in the intestine, it is unlikely that it affected our results due to the very small amount required to balance glycerol intake between PA-TG and Ca-FA. The DM concentration of forages was determined twice weekly, and diets were adjusted when necessary. Cows were housed in tie-stalls throughout the entire experiment and milked twice daily (0400 and $1500 \mathrm{~h}$ ). Access to feed was blocked from 0800 to 1000 $\mathrm{h}$ for collection of orts and offering of new feed. Cows were fed $115 \%$ of expected intake at $1000 \mathrm{~h}$ daily. Water was available ad libitum in each stall and stalls were bedded with sawdust and cleaned twice daily.

Samples and data for production and digestibility variables were collected during the last $5 \mathrm{~d}$ of each treatment period (d 17 to 21). Feed ingredients and orts were collected daily and composited by period and analyzed for DM, NDF, CP, starch, and FA contents as described by Boerman and Lock (2014). Fecal (500 g) samples were collected every $15 \mathrm{~h}$, resulting in 8 samples per cow per period, and nutrient digestibility was calculated using indigestible NDF (iNDF) as an internal marker as previously described (Piantoni et al., 2013). Fat supplements were composited by period and chemical composition and particle size distribution determined (de Souza et al., 2017; Supplemental Table S1; https://doi.org/10.3168/jds.2017-13560). Individual milk samples were analyzed for fat, true protein, and lactose by mid-infrared spectroscopy (AOAC, 1990; method 972.160), and for FA using GLC (Lock et al., 2013). Yields of 3.5\% FCM, ECM, and milk components were calculated using milk yield and component concentrations for each milking, summed for a daily total, and averaged for each collection period. Body weight was measured 3 times per week, and 4 trained investigators determined BCS on a 5-point scale in 0.25-point increments on the last day of each period (Wildman et al., 1982). We determined energy partitioning using the procedures described by Boerman et al. (2015b). Data were used to calculate milk energy output and body tissue gain throughout each treatment period. Milk energy output (Mcal/d) was calculated according to $\mathrm{NRC}(2001)$ : milk energy output $(\mathrm{Mcal} / \mathrm{d})=[9.29$ $\times$ fat $(\mathrm{kg})+5.63 \times$ true protein $(\mathrm{kg})+3.95 \times$ lactose $(\mathrm{kg})]$, where each component was based on the average output of a cow during the 5-d sampling period. Mean daily $\mathrm{BW}$ change $(\Delta \mathrm{BW}, \mathrm{kg} / \mathrm{d})$ was calculated for each cow within period by linear regression after 2 iterations of removing outliers. Energy partitioned to body tissue (Mcal/d) was estimated according to NRC (2001): body tissue gain $(\mathrm{Mcal} / \mathrm{d})=[(2.88+1.036 \times \mathrm{BCS}) \times$ 
$\triangle \mathrm{BW}$, where BCS was the average BCS for each cow during a 21-d period. Apparent $\mathrm{NE}_{\mathrm{L}}$ concentration of the diet was calculated from the digestibility results, as described by Harvatine and Allen (2006).

Data were analyzed using the MIXED procedure of SAS (version 9.2; SAS Institute Inc., Cary, NC). The statistical model included the fixed effect of treatment and period, as well as 2-way interactions between these factors, and the random effects of treatment sequence and cow nested within sequence. The interaction between period and treatment was initially included in the model and removed because $P>0.20$ for all variables. Two preplanned contrasts were used to evaluate (1) the effect of fat-supplemented treatments [CON vs. fat-supplemented treatments; $1 / 2$ (PA-TG + Ca-FA)], and (2) the effect of fat supplement (PA-TG vs. CaFA). Contrasts were declared significant at $P \leq 0.05$ and trends at $0.05<P \leq 0.10$.
Overall, fat supplementation did not affect DMI compared with CON $(P>0.10$; Table 2), but Ca-FA reduced DMI by $0.90 \mathrm{~kg} / \mathrm{d}$ compared with PA-TG $(P<$ $0.05)$. This is supported by several reviews that observed that feeding calcium salts of palm FA reduced DMI (Allen, 2000; Rabiee et al., 2012; Weld and Armentano, 2017). The effects of fat supplementation on DMI vary according to the source of fat fed (Rabiee et al., 2012), and the hypophagic effect of feeding fat seems to be more pronounced for unsaturated than for saturated FA supplements (Harvatine and Allen, 2006), with DMI decreasing linearly as the degree of unsaturation increases (Pantoja et al., 1994). The more pronounced decrease in DMI for unsaturated FA is likely mediated in part by increased secretion of gut peptides related to satiety (i.e., cholecystokinin and glucagon-like peptide 1; Relling and Reynolds, 2007; Bradford et al., 2008). We observed that fat supplementation reduced NDF

Table 1. Ingredient and nutrient composition of treatment diets

\begin{tabular}{|c|c|c|c|}
\hline \multirow[b]{2}{*}{ Item } & \multicolumn{3}{|c|}{ Treatment $^{1}$} \\
\hline & $\mathrm{CON}$ & PA-TG & $\mathrm{Ca}-\mathrm{FA}$ \\
\hline \multicolumn{4}{|l|}{ Ingredient, $\%$ of $\mathrm{DM}$} \\
\hline Corn silage & 22.1 & 22.1 & 22.1 \\
\hline Alfalfa silage & 15.3 & 15.3 & 15.3 \\
\hline Wheat straw & 4.60 & 4.60 & 4.60 \\
\hline Ground corn & 12.0 & 12.0 & 12.0 \\
\hline High-moisture corn & 12.0 & 12.0 & 12.0 \\
\hline Soybean meal & 14.3 & 14.3 & 14.3 \\
\hline Soyhulls & 9.39 & 7.70 & 7.94 \\
\hline Whole cottonseed & 7.0 & 7.0 & 7.0 \\
\hline Palmitic acid triglyceride supplement ${ }^{2}$ & - & 1.69 & - \\
\hline Ca-salts of palm FA supplement ${ }^{3}$ & - & - & 1.80 \\
\hline Glycerin & - & - & 0.15 \\
\hline Mineral and vitamin $\operatorname{mix}^{4}$ & 2.0 & 2.0 & 2.0 \\
\hline Limestone & 0.60 & 0.60 & 0.10 \\
\hline Sodium bicarbonate & 0.71 & 0.71 & 0.71 \\
\hline \multicolumn{4}{|l|}{ Nutrient composition, $\%$ of $\mathrm{DM}^{5}$} \\
\hline DM & 58.6 & 58.6 & 58.6 \\
\hline $\mathrm{NDF}$ & 31.0 & 29.9 & 30.1 \\
\hline $\mathrm{CP}$ & 16.7 & 16.6 & 16.6 \\
\hline Starch & 26.0 & 26.0 & 25.9 \\
\hline FA & 3.37 & 4.82 & 4.84 \\
\hline 16:0 & 0.55 & 1.68 & 1.22 \\
\hline 18:0 & 0.08 & 0.16 & 0.16 \\
\hline cis-9 18:1 & 0.59 & 0.79 & 1.17 \\
\hline cis-9,cis-12 18:2 & 1.72 & 1.75 & 1.85 \\
\hline cis-9,cis-12,cis-15 18:3 & 0.19 & 0.19 & 0.19 \\
\hline
\end{tabular}

${ }^{1} \mathrm{CON}=$ control, no addition of supplemental fatty acids; PA-TG $=1.5 \%$ of fatty acids added as a palmitic acid-enriched triglyceride supplement; $\mathrm{Ca}-\mathrm{FA}=1.5 \%$ of fatty acids added as a calcium salts of palm fatty acid supplement.

${ }^{2}$ BergaFat T300 (Berg + Schmidt GmbH \& Co. KG, Hamburg, Germany). The supplement contained (g/100 $\mathrm{g}$ of fatty acid) 1.1 of $\mathrm{C} 14: 0,76.8$ of $\mathrm{C} 16: 0,5.05$ of $\mathrm{C} 18: 0,13.6$ of cis-9 C18:1, and 89.8\% total fatty acids.

${ }^{3}$ Megalac (Church \& Dwight Co. Inc., Princeton, NJ). The supplement contained (g/100 g of fatty acid) 0.92 of C14:0, 45.4 of $\mathrm{C} 16: 0,0.69$ of $\mathrm{C} 18: 0,38.1$ of cis-9 $\mathrm{C} 18: 1$, and $85 \%$ total fatty acids.

${ }^{4}$ Vitamin and mineral mix contained $34.1 \%$ dry ground shelled corn, $25.6 \%$ white salt, $21.8 \%$ calcium carbonate, $9.1 \%$ Biofos (The Mosaic Co., Plymouth, MN), 3.9\% magnesium oxide, $2 \%$ soybean oil, and $<1 \%$ of each of the following: manganese sulfate, zinc sulfate, ferrous sulfate, copper sulfate, iodine, cobalt carbonate, vitamin $\mathrm{E}$, vitamin $\mathrm{A}$, vitamin $\mathrm{D}$, and selenium.

${ }^{5}$ Expressed as percent of as fed. 
Table 2. Nutrient intake, nutrient digestibility, BW, BCS, and calculated energy for cows fed treatment diets $(\mathrm{n}=15)$

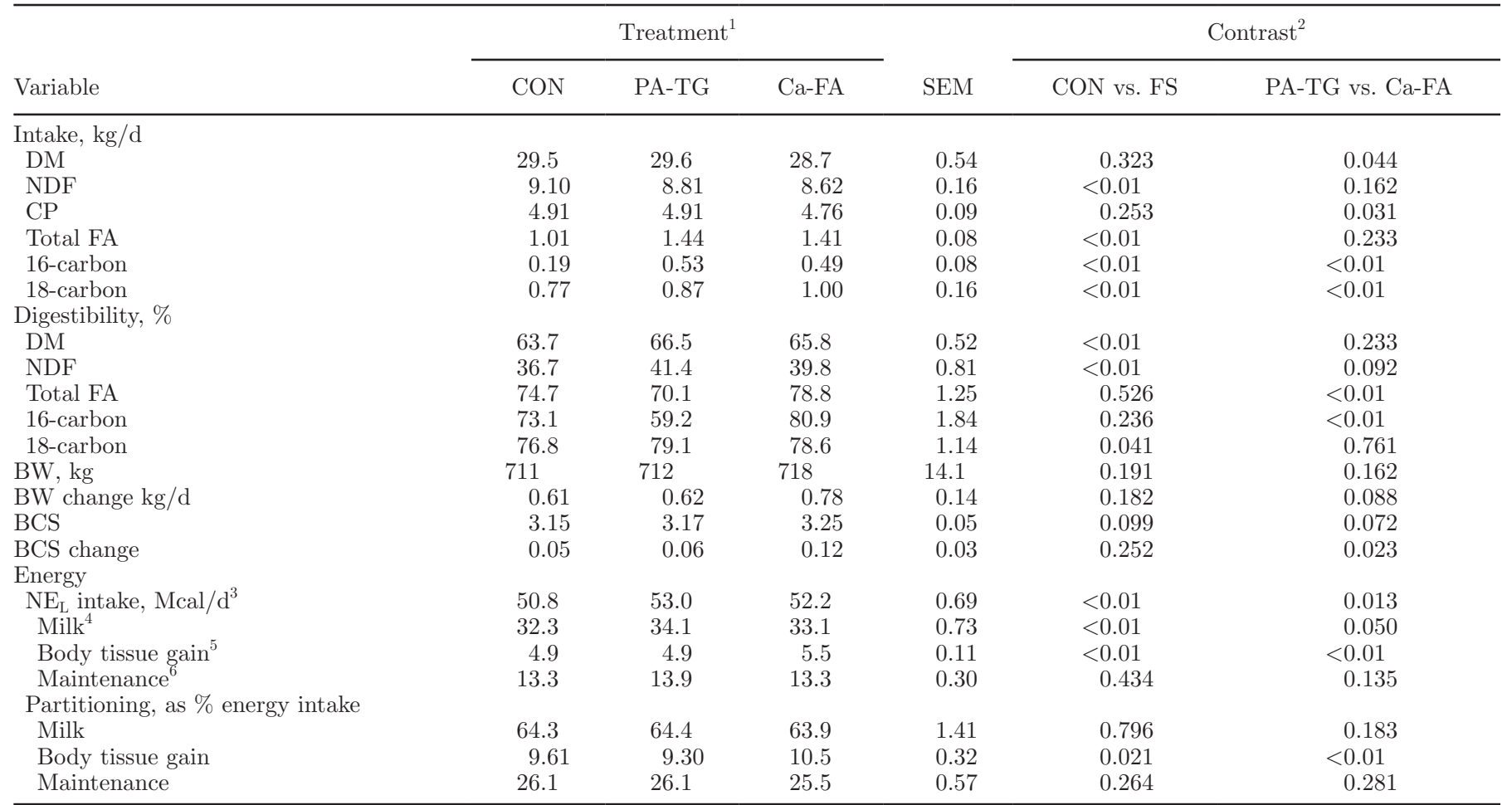

${ }^{1} \mathrm{CON}=$ control, no addition of supplemental fatty acids; PA-TG $=1.5 \%$ of fatty acids added as a palmitic acid-enriched triglyceride supplement; $\mathrm{Ca}-\mathrm{FA}=1.5 \%$ of fatty acids added as a calcium salts of palm fatty acid supplement.

${ }^{2} P$-values associated with contrasts: CON vs. FS $=P$-value associated with differences between control and fat-supplemented treatments $[(\mathrm{PA}-$ $\mathrm{TG}+\mathrm{Ca}-\mathrm{FA}) / 2]$; PA-TG vs. Ca-FA $=P$-value associated with differences between PA-TG and Ca-FA treatments.

${ }^{3}$ From digestibility equations (NRC, 2001) according to Harvatine and Allen (2006) based on nutrient digestibility results collected during the last $5 \mathrm{~d}$ of each treatment period.

${ }^{4}$ From NRC $(2001)$ equations: Milk energy $=\mathrm{kg}$ of milk $\times[(0.0929 \times$ milk fat $\%)+(0.0563 \times$ milk protein $\%)+(0.0395 \times$ milk lactose $\%)]$.

${ }^{5}$ From NRC (2001) equations: Body tissue gain $(\mathrm{Mcal} / \mathrm{d})=[(2.88+1.036 \times \mathrm{BCS}) \times$ mean daily change in BW $]$.

${ }^{6}$ From NRC (2001) equations: $0.08 \times \mathrm{BW}^{0.75}$.

intake by $0.39 \mathrm{~kg} / \mathrm{d}$ compared with CON $(P<0.01)$, mainly a result of the lower NDF content in these diets due to the removal of soyhulls in the fat-supplemented treatments. As expected, fat-supplemented treatments increased total FA intake $(0.42 \mathrm{~kg} / \mathrm{d})$ compared with CON $(P<0.01)$. The PA-TG treatment increased 16-carbon FA intake $(0.04 \mathrm{~kg} / \mathrm{d})$ compared with $\mathrm{Ca}$ FA $(P<0.01)$, whereas Ca-FA increased 18-carbon FA intake $(0.13 \mathrm{~kg} / \mathrm{d})$ compared with PA-TG $(P<0.01)$. Fat-supplemented treatments increased NDF digestibility compared with CON $(P<0.01 ; 3.90$ percentage units). In a recent meta-analysis, Weld and Armentano (2017) observed that calcium salts of palm FA did not affect NDF digestibility, whereas saturated prilled fat containing a mixture of $\mathrm{C} 16: 0$ and $\mathrm{C} 18: 0$ increased NDF digestibility. The increase in NDF digestibility with Ca-FA might be associated with the decrease in DMI in this treatment. Compared with Ca-FA, PA-TG tended to increase NDF digestibility $(P<0.10 ; 1.60$ percentage units), which is consistent with previous studies feeding palmitic acid-enriched FA supplements (de Souza et al., 2017; Rico et al., 2017). The increase in NDF digestibility with C16:0 supplementation may be associated with an increase in retention time driven by an increase in cholecystokinin secretion (Piantoni et al., 2013) or improvements in growth of Butyrivibrio bacteria in the rumen (Hackmann and Firkins, 2015).

Compared with CON, fat supplementation increased 18-carbon FA digestibility $(P<0.05 ; 2.0$ percentage units), whereas it did not affect digestibility of total or 16-carbon FA (both $P>0.10$ ). Under normal conditions, most FA reaching the intestine of ruminants are free fatty acids (Doreau and Chilliard, 1997), and therefore lipase activity is lower than in nonruminants (Moore and Christie, 1984). Previous studies have reported lower FA digestibility for fat supplements fed as TG than for those fed as FA supplements (Elliott et al., 1999; Weiss and Wyatt, 2004). With that, some authors postulated that lipolysis in the small intestine might be a rate-limiting step to FA digestion (Pantoja 
et al., 1995). Because several lipases are active only at the distal end of the small intestine, they may be unable to hydrolyze large amounts of duodenal TG when these supplements are fed, therefore possibly limiting intestinal digestibility (Jenkins and Jenny, 1992). In our study, we observed that PA-TG reduced total FA digestibility by 8.70 percentage units compared with Ca-FA $(P<0.01)$. This reduction in total FA digestibility by PA-TG was a result of the decrease in 16-carbon FA digestibility $(P<0.01 ; 21.7$ percentage units). However, the decrease in FA digestibility was smaller than that previously reported in other studies that fed saturated TG supplements, in which total FA digestibility ranged from 33 to $62 \%$ (e.g., Pantoja et al., 1995; Elliott et al., 1999; Weiss and Wyatt, 2004). This difference may be associated with differences in the FA profile of the supplements being evaluated and potentially differences in lipolysis in the rumen. The supplemental TG in the previously described studies contained high concentrations of SFA, mainly C18:0 (31 to 58\%), whereas the TG supplement in our study contained only $\sim 5 \% \mathrm{C} 18: 0$. In a meta-analysis evaluating the digestibility of individual FA using duodenally cannulated cows, Boerman et al. (2015a) determined that as the amount of $\mathrm{C} 18: 0$ reaching the duodenum increased, the digestibility of C18:0 decreased linearly across fat-supplemented and non-fat-supplemented diets encompassing a wide range of C18:0 duodenal flows. In addition, Johnson et al. (1974) reported lower intestinal hydrolysis in sheep for tallow compared with coconut oil, olive oil, or corn oil. This was attributed to lower lipase activity resulting from lower solubility and poor emulsification of tallow due to its FA profile. Therefore, the lower solubility of TG enriched with C18:0 may increase the need for emulsification compounds to form micelles and possibly reduce the time of action of intestinal lipases and for FA absorption. Alternatively, although we did not measure it in our study, our PA-TG supplement could have been partially hydrolyzed in the rumen, resulting in less intact TG reaching the intestine compared with previous studies that fed partially or fully hydrogenated tallow. This hypothesis deserves further investigation. Similar to our results, Weiss et al. (2011) observed that total FA digestibility was reduced by $\sim 8$ percentage points when a saturated TG supplement containing $72 \%$ C16:0 and 5\% C18:0 was fed compared with a control diet. By using a Lucas test, we estimated true digestibility of the fat supplements in our study as 62 and $81 \%$ for PATG and Ca-FA, respectively (Supplemental Figure S1; https://doi.org/10.3168/jds.2017-13560). Our result for the PA-TG supplement is similar to the value estimated (56\%) by Weiss et al. (2011) for their saturated TG supplement with a similar FA profile.
Interestingly, we also observed that Ca-FA had the highest FA digestibility, including 16- and 18-carbon FA. Recently, Rico et al. (2017) observed that 16-carbon FA digestibility was reduced when feeding a palmitic acid-enriched supplement $(85 \% \mathrm{C} 16: 0)$ to a greater extent in a soyhulls basal diet than in a whole cottonseed basal diet. Although total flow of FA at the duodenum affects FA digestibility (Boerman et al., 2015a), these findings support the hypothesis that the profile of FA entering the duodenum is a critical factor affecting FA digestibility. Additionally, previous results have suggested that cis-9 C18:1 has greater digestibility than C18:0 and C16:0 (Boerman et al., 2015a), and cis-9 C18:1 is thought to have amphiphilic properties (Moate et al., 2004). This is supported by Freeman (1969), who examined the amphiphilic properties of polar lipid solutes and found that cis-9 C18:1 had a positive effect on the micellar solubility of $\mathrm{C} 18: 0$. It is important to point out that even though cis-9 C18:1 was the main FA in our Ca-FA supplement, it is likely that this treatment increased rumen outflow of other 18-carbon FA, including C18:0. Additional research is required to understand the mechanisms by which cis-9 C18:1 may increase digestibility of other FA.

Compared with CON, fat-supplemented treatments increased milk yield by $1.05 \mathrm{~kg} / \mathrm{d}(P<0.05$; Table 3$)$, $3.5 \% \mathrm{FCM}$ by $2.20 \mathrm{~kg} / \mathrm{d}(P<0.01)$, and ECM by 1.80 $\mathrm{kg} / \mathrm{d}(P<0.01)$. Also, PA-TG increased milk fat yield $(P<0.05 ; 50 \mathrm{~g} / \mathrm{d})$ and milk energy output $(P<0.05$; $1.0 \mathrm{Mcal} / \mathrm{d})$, and tended to increase milk fat content $(P$ $<0.10 ; 0.07$ percentage units $)$ and $\operatorname{ECM}(P<0.10 ; 1.0$ $\mathrm{kg} / \mathrm{d}$ ) compared with Ca-FA. These results are in agreement with most of our short-term studies feeding palmitic acid-enriched free FA supplements (fed at 1.5 to $2.0 \%$ of diet DM) that have indicated increases in milk fat yield of $\sim 100 \mathrm{~g} / \mathrm{d}$ compared with nonfat control diets (Piantoni et al., 2013; Lock et al., 2013; de Souza et al., 2016). The fat-supplemented treatments reduced the concentration $(2.90 \mathrm{~g} / 100 \mathrm{~g}$ of FA) and yield $(23 \mathrm{~g} / \mathrm{d})$ of de novo $(P<0.05)$ milk FA and increased the concentrations (2.15 and $0.75 \mathrm{~g} / 100 \mathrm{~g}$ of FA, respectively) and yields (43 and $52 \mathrm{~g} / \mathrm{d}$, respectively) of mixed and preformed $(P<0.05)$ milk FA compared with $\mathrm{CON}$. The PA-TG treatment increased the yield of 16-carbon milk FA by $66 \mathrm{~g} / \mathrm{d}$ compared with Ca-FA $(P<0.01)$. The increase in 16-carbon milk FA with PA-TG was due to the increase in concentration and yield of C16:0 $(P<0.01$; Supplemental Tables S2 and S3; https:// doi.org/10.3168/jds.2017-13560). Also, Ca-FA reduced the concentration $(P<0.01 ; 1.20 \mathrm{~g} / 100 \mathrm{~g}$ of FA) and tended to reduce the yield of de novo $(P<0.10 ; 20 \mathrm{~g} / \mathrm{d})$ milk FA compared with PA-TG. In contrast, compared with PA-TG, Ca-FA increased the concentration (3.10 $\mathrm{g} / 100 \mathrm{~g}$ of $\mathrm{FA})$ and yield $(60 \mathrm{~g} / \mathrm{d})$ of preformed milk 
Table 3. Milk yield, milk composition, and milk fatty acids (FA) for cows fed treatment diets $(\mathrm{n}=15)$

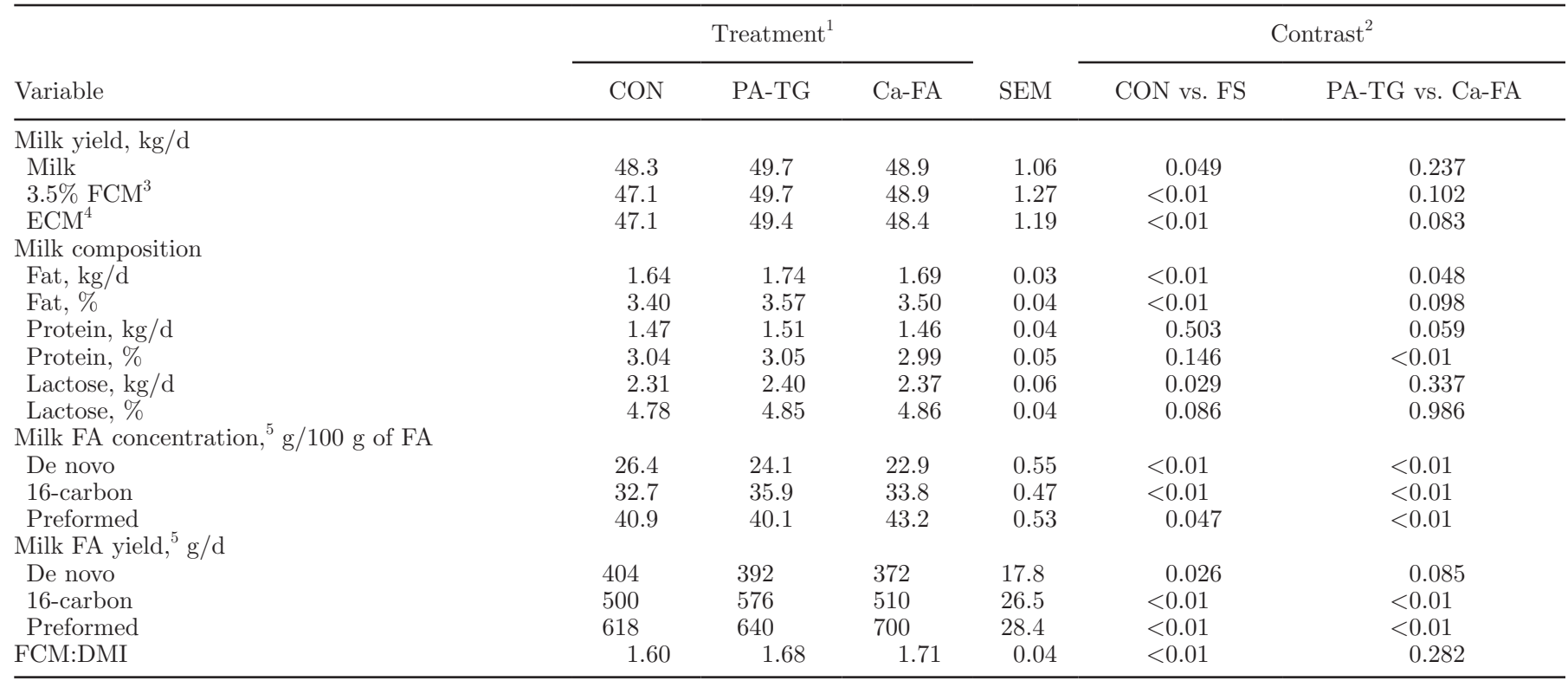

${ }^{1} \mathrm{CON}=$ control, no addition of supplemental fatty acids; PA-TG $=1.5 \%$ of fatty acids added as a palmitic acid-enriched triglyceride supplement; Ca-FA $=1.5 \%$ of fatty acids added as a calcium salts of palm fatty acid supplement.

${ }^{2} P$-values associated with contrasts: $\mathrm{CON}$ vs. $\mathrm{FS}=P$-value associated with differences between control and fat-supplemented treatments $[(\mathrm{PA}$ $\mathrm{TG}+\mathrm{Ca}-\mathrm{FA}) / 2] ; \mathrm{PA}-\mathrm{TG}$ vs. Ca-FA $=P$-value associated with differences between PA-TG and Ca-FA treatments.

${ }^{3} 3.5 \% \mathrm{FCM}=[(0.4324 \times \mathrm{kg}$ of milk $)+(16.216 \times \mathrm{kg}$ of milk fat $)]$.

${ }^{4} \mathrm{ECM}=[(0.327 \times \mathrm{kg}$ of milk $)+(12.95 \times \mathrm{kg}$ of milk fat $)+(7.20 \times \mathrm{kg}$ of milk protein $)]$.

${ }^{5}$ De novo FA originate from mammary de novo synthesis $(<16 \mathrm{C})$, preformed FA originated from extraction from plasma $(>16 \mathrm{C})$, and $16-\mathrm{C}$ FA originate from both sources (C16:0 plus cis-9 C16:1).

FA (both $P<0.01$ ) due to the increase in the yield of several 18-carbon FA in milk fat, including cis-9 C18:1 $(P<0.01)$, cis-9, cis-12 C18:2 $(P<0.01)$, cis-9, trans-11 C18:2 $(P<0.05)$, and cis-9,cis-12,cis-15 C18:3 $(P<$ 0.05; Supplemental Table S3; https://doi.org/10.3168/ jds.2017-13560). The substitution effect of preformed for de novo milk FA has been reported previously ( $\mathrm{He}$ and Armentano, 2011; He et al., 2012), in which the reduction in yield of de novo milk FA was compensated for by an increase in the yield of preformed milk FA when fat supplements were fed.

Compared with CON, fat-supplemented treatments did not affect milk protein content and yield $(P>0.10)$ but tended to increase content (0.08 percentage units) and yield $(70 \mathrm{~g} / \mathrm{d})$ of milk lactose $(P<0.10)$. The CaFA treatment decreased milk protein content by 0.06 percentage units $(P<0.01)$ and tended to decrease milk protein yield by $45 \mathrm{~g} / \mathrm{d}(P<0.10)$ compared with PA-TG. Supplemental fat often reduces milk protein content compared with nonfat controls (Rabiee et al., 2012) possibly due to decreased glucose availability, development of insulin resistance, increased efficiency of milk production, reduced plasma somatotropin, and reduced amino acid supply to the mammary gland (Cant et al., 1993; Wu and Huber, 1994). In our study, the reduction in milk protein concentration with the Ca-FA treatment compared with PA-TG was likely due to the lower DMI and CP intake. The reduction in DMI would suggest less MP available for milk protein synthesis (Weiss et al., 2011).

Compared with CON, fat-supplemented treatments increased calculated $\mathrm{NE}_{\mathrm{L}}$ intake by $1.80 \mathrm{Mcal} / \mathrm{d}$, milk energy output by $1.30 \mathrm{Mcal} / \mathrm{d}$, and energy in body reserves by $0.30 \mathrm{Mcal} / \mathrm{d}$ (all $P<0.01$; Table 2). The Ca-FA treatment increased energy allocated to body reserves $(0.60 \mathrm{Mcal} / \mathrm{d})$ and energy partitioning toward body reserves (1.20 percentage units; both $P<$ $0.01)$ and tended to increase BW change $(0.16 \mathrm{~kg} / \mathrm{d}$; $P<0.10)$ and increased BCS change $(0.06$ units; $P$ $<0.05)$ compared with PA-TG. Also compared with PA-TG, Ca-FA increased the concentration and yield of trans-10 C18:1 in milk fat. Similarly, Boerman et al. (2015b) observed a positive correlation between milk fat trans-10 C18:1 content and change in BCS; however, the increase in milk trans-10 C18:1 was not associated with changes in milk fat yield. The Ca-FA treatment provided a higher load of UFA in the diet, which likely overcome normal rumen biohydrogenation capacity and altered biohydrogenation pathways. This may be associated with repartitioning of energy by reducing 
milk energy output and increasing body fat reserves. Although in our study we did not detect levels of trans10,cis-12 C18:2 in milk fat for most of our samples, Harvatine et al. (2009) reported that during abomasal infusions of trans-10,cis-12 C18:2, the expression of lipogenic enzymes was downregulated in mammary tissue and upregulated in adipose tissue. Conversely, Urrutia and Harvatine (2017) observed reduced lipogenic capacity of adipose tissue explants without changes in gene expression of key lipogenic enzymes during $4 \mathrm{~d}$ of trans-10,cis-12 C18:2 infusion of low-producing cows, which suggested that energy partitioning under milk fat depression-induced conditions may be affected by physiological state. Further studies are needed to evaluate the association between changes in biohydrogenation pathways and partitioning of energy across different tissues under different physiological conditions, as well as changes in energy partitioning driven by fat supplementation in long-term studies. Additionally, it is important to note that our design used 21-d periods, and changes in BW in short-term studies may be confounded by differences in gut fill between diets (Weiss et al., 2011). Although this consideration is important, we measured BW 3 times per week, which likely improved the accuracy of our measurements compared with studies that only measured BW at the beginning and end of the study.

In conclusion, our results demonstrate that calcium salts of palm FA supplements have higher FA digestibility than palmitic acid-enriched TG supplements. Although the palmitic acid-enriched TG supplement reduced FA digestibility, the reduction was smaller than previously reported in the literature for highly saturated TG supplements with higher concentrations of C18:0, less total UFA, and lower iodine value. Feeding a palmitic acid-enriched triglyceride supplement increased milk energy output due to increased yields of milk and milk fat, whereas feeding a calcium salts of palm FA supplement increased FA digestibility and energy partitioned to body reserves.

\section{ACKNOWLEDGMENTS}

The authors acknowledge Berg \& Schmidt Functional Lipids (Hamburg, Germany) and Al Ames (NutriLinx, Burlington, VT) for financial support and donation of the supplements. We acknowledge C. L. Preseault, Y. Sun, J. L. Garver, S. Schmidt, M. Western, K. Wu, K. Spaans, J. L. Spaans and T. N. Bryant (all in the Department of Animal Science, Michigan State University) and the staff of the Michigan State University Dairy Cattle Teaching and Research Center for their assistance in this experiment. Jonas de Souza was supported by a PhD fellowship from Coordenação de Aperfoiçamento de Pessoal de Nivel Superior (CAPES) from the Brazilian Ministry of Education (Brasilia, DF, Brazil).

\section{REFERENCES}

Allen, M. S. 2000. Effects of diet on short-term regulation of feed intake by lactating dairy cattle. J. Dairy Sci. 83:1598-1624.

AOAC. 1990. Official Methods of Analysis. 15th ed. Assoc. Off. Anal. Chem., Arlington, VA.

Boerman, J. P., J. L. Firkins, N. R. St-Pierre, and A. L. Lock. 2015a. Intestinal digestibility of long-chain fatty acids in lactating dairy cows: A meta-analysis and meta regression. J. Dairy Sci. 98:88898903

Boerman, J. P., and A. L. Lock. 2014. Effect of unsaturated fatty acids and triglycerides from soybeans on milk fat synthesis and biohydrogenation intermediates in dairy cattle. J. Dairy Sci. 97:7031-7042.

Boerman, J. P., S. B. Potts, M. J. VandeHaar, and A. L. Lock. 2015b. Effects of partly replacing dietary starch with fiber and fat on milk production and energy partitioning. J. Dairy Sci. 98:7264-7276.

Bradford, B. J., K. J. Harvatine, and M. S. Allen. 2008. Dietary unsaturated fatty acids increased plasma glucagon-like peptide-1 and cholecystokinin and may decrease premeal ghrelin in lactating dairy cows. J. Dairy Sci. 91:1443-1450.

Cant, J. P., E. J. DePeters, and R. L. Baldwin. 1993. Mammary amino acid utilization in dairy cows fed fat and its relationship to milk protein depression. J. Dairy Sci. 76:762-774.

de Souza, J., J. L. Garver, C. L. Preseault, and A. L. Lock. 2017. Short communication: Effects of prill size of a palmitic acid-enriched fat supplement on the yield of milk and milk components, and nutrient digestibility of dairy cows. J. Dairy Sci. 100:379-384.

de Souza, J., C. L. Preseault, and A. L. Lock. 2016. Short communication: Lactational responses to palmitic acid supplementation when replacing soyhulls or dry ground corn. J. Dairy Sci. 99:1945-1950.

Doreau, M., and Y. Chilliard. 1997. Digestion and metabolism of dietary fat in farm animals. Br. J. Nutr. 78(Suppl. 1):S15-S35.

Elliott, J. P., J. K. Drackley, A. D. Beaulieu, C. G. Aldrich, and N. R. Merchen. 1999. Effects of saturation and esterification of fat sources on site and extent of digestion in steers: Digestion of fatty acids, triglycerides, and energy. J. Anim. Sci. 77:1919-1929.

Freeman, C. P. 1969. Properties of fatty acids in dispersions of emulsified lipid and bile salt and the significance of these properties in fat absorption in the pig and the sheep. Br. J. Nutr. 23:249-263.

Hackmann, T. J., and J. L. Firkins. 2015. Electron transport phosphorylation in rumen butyrivibrios: Unprecedented ATP yield for glucose fermentation to butyrate. Front. Microbiol. 6:622. https:// doi.org/10.3389/fmicb.2015.00622.

Harvatine, K. J., and M. S. Allen. 2006. Effects of fatty acid supplements on milk yield and energy balance of lactating dairy cows. J. Dairy Sci. 89:1081-1091.

Harvatine, K. J., J. W. Perfield, and D. E. Bauman. 2009. Expression of enzymes and key regulators of lipid synthesis is upregulated in adipose tissue during CLA-induced milk fat depression in dairy cows. J. Nutr. 139:849-854.

He, M., and L. E. Armentano. 2011. Effect of fatty acid profile in vegetable oils and antioxidant supplementation on dairy cattle performance and milk fat depression. J. Dairy Sci. 94:2481-2491.

He, M., K. L. Perfield, H. B. Green, and L. E. Armentano. 2012. Effect of dietary fat blend enriched in oleic or linoleic acid and monensin supplementation on dairy cattle performance, milk fatty acid profiles, and milk fat depression. J. Dairy Sci. 95:1447-1461.

Jenkins, T. C., and B. F. Jenny. 1992. Nutrient digestion and lactation performance of dairy cows fed combinations of prilled fat and canola oil. J. Dairy Sci. 75:796-803.

Johnson, T. O., G. E. Mitchell Jr., R. E. Tucker, and G. T. Schelling. 1974. Pancreatic lipase secretion by sheep. J. Anim. Sci. 39:947951. 
Lock, A. L., C. L. Preseault, J. E. Rico, K. E. DeLand, and M. S. Allen. 2013. Feeding a C16:0-enriched fat supplement increased the yield of milk fat and improved conversion of feed to milk. J. Dairy Sci. 96:6650-6659.

Moate, P. J., W. Chalupa, T. C. Jenkins, and R. C. Boston. 2004. A model to describe ruminal metabolism and intestinal absorption of long chain fatty acids. Anim. Feed Sci. Technol. 112:79-105.

Moore, J. H., and W. W. Christie. 1984. Digestion, absorption and transport of fats in ruminant animals. Pages 123-149 in Fats in Animal Nutrition. J. Wisema, ed. Butterworths, London, UK.

NRC. 2001. Nutrient Requirements of Dairy Cattle. 7th rev. ed. National Acad. Sci., Washington, DC.

Palmquist, D. L. 1991. Influence of source and amount of dietary fat on digestibility in lactating cows. J. Dairy Sci. 74:1354-1360.

Palmquist, D. L. 1994. The role of dietary fats in efficiency of ruminants. J. Nutr. 124(Suppl.):1377S-1382S.

Pantoja, J., J. L. Firkins, and M. L. Eastridge. 1995. Site of digestion and milk production by cows fed fats differing in saturation, esterification, and chain length. J. Dairy Sci. 78:2247-2258.

Pantoja, J., J. L. Firkins, M. L. Eastridge, and B. L. Hull. 1994. Effects of fat saturation and source of fiber on site of nutrient digestion and milk production by lactating dairy cows. J. Dairy Sci. $77: 2341-2356$

Piantoni, P., A. L. Lock, and M. S. Allen. 2013. Palmitic acid increased yields of milk and milk fat and nutrient digestibility across production level of lactating cows. J. Dairy Sci. 96:7143-7154.

Rabiee, A. R., K. Breinhild, W. Scott, H. M. Golder, E. Block, and I. J. Lean. 2012. Effect of fat additions to diets of dairy cattle on milk production and components: A meta-analysis and metaregression. J. Dairy Sci. 95:3225-3247.

Relling, A. E., and C. K. Reynolds. 2007. Feeding rumen-inert fats differing in their degree of saturation decreases intake and increases plasma concentrations of gut peptides in lactating dairy cows. J. Dairy Sci. 90:1506-1515.

Rico, D. E., Y. Ying, and K. J. Harvatine. 2014a. Comparison of enriched palmitic acid and calcium salts of palm fatty acids distillate fat supplements on milk production and metabolic profiles of highproducing dairy cows. J. Dairy Sci. 97:5637-5644.

Rico, J. E., M. S. Allen, and A. L. Lock. 2014b. Compared with stearic acid, palmitic acid increased the yield of milk fat and improved feed efficiency across production level of cows. J. Dairy Sci. 97:1057-1066.

Rico, J. E., J. de Souza, M. S. Allen, and A. L. Lock. 2017. Nutrient digestibility and milk production responses to increasing levels of palmitic acid supplementation vary in cows receiving diets with or without whole cottonseed. J. Anim. Sci. 95:436-446.

Urrutia, N., and K. J. Harvatine. 2017. Effect of conjugated linoleic acid and acetate on milk fat synthesis and adipose lipogenesis in lactating dairy cows. J. Dairy Sci. 100:5792-5804.

Weiss, W. P. J. M. Pinos-Rodríguez, and D. J. Wyatt. 2011. The value of different fat supplements as sources of digestible energy for lactating dairy cows. J. Dairy Sci. 94:931-939.

Weiss, W. P., and D. J. Wyatt. 2004. Digestible energy values of diets with different fat supplements when fed to lactating dairy cows. J. Dairy Sci. 87:1446-1454

Weld, K. A., and L. E. Armentano. 2017. The effects of adding fat to diets of lactating dairy cows on total-tract neutral detergent fiber digestibility: A meta-analysis. J. Dairy Sci. 100:1766-1779.

Wildman, E. E., G. M. Jones, P. E. Wagner, and R. L. Bowman. 1982. A dairy cow body condition scoring system and its relationship to selected production characteristics. J. Dairy Sci. 65:495-501.

Wu, Z., and J. T. Huber. 1994. Relationship between dietary-fat supplementation and milk protein concentration in lactating cows- $\mathrm{A}$ review. Livest. Prod. Sci. 39:141-155. 